\title{
Pengaruh Keputusan Pembelian Melalui Online Shopping Pada Mahasiswa STIE AUB Surakarta
}

\author{
Yenni Khristiana*, Andri Octaviani \\ Dosen Program Studi Akuntansi \\ STIE Adi Unggul Bhirawa Surakarta \\ Yenni.kristi@stie-aub.ac.id
}

2019

\begin{abstract}
Abstraksi
Tujuan penelitian ini adalah untuk mengetahui Keputusan Pembelian Online pada mahasiswa STIE AUB Surakarta tahun penelitian 2018. Variabel yang diambil antara lain Kemenarikan Desain, Reputasi Vendor, Persepsi Kemudahan Belanja, Sikap Belanja Online dan Kepercayaan. Kelima Variabel tersebut kemudian diuji terhadap Keputusan Pembelian Online. Populasi merupakan mahasiswa STIE AUB Surakarta yang pernah membeli melalui online. Sampel di dapatkan 107 Mahasiswa. Data hasil penelitian dianalisis dengan teknik uji statistik deskriptif, uji linieritas, uji hipotesis (uji t, uji F, koefesien determinasi dan korelasi). Metode analisis yang digunakan adalah regresi linier berganda. Hasil penelitian menunjukan bahwa Sikap Belanja Online berpengaruh positif dan signifikan terhadap Keputusan Pembelian Online, Variabel Reputasi vendor dan Kepercayaan berpengaruh positif namun tidak signifikan terhadap Keputusan Pembelian Online. Sedangkan Kemenarikan Desain dan Persepsi Kemudahan Belanja berpengaruh negatif dan tidak signifikan terhadap Keputusan Pembelian Online.

Kata kunci: Keputusan Pembelian Online, Sikap Belanja Online, Reputasi Vendor dan Kepercayaan
\end{abstract}

\section{A. PENDAHULUAN}

Internet mulai menjadi bagian dari kehidupan sehari-hari rakyat Indonesia. Potensi $e$ commerce terlihat dari angka $77 \%$ dari penggunaan internet digunakan untuk mencari informasi produk dan berbelanja online, pelanggan online shop yang mencapai 8,7 juta orang, dan nilai transaksi yang diprediksi mencapai US\$ 4,89 Miliar pada tahun 2016. Ini meningkat dibanding tahun 2015. Sudah saatnya Indonesia sendiri yang menikmati perkembangan tersebut, bukan layanan dari luar negeri (www.kominfo.go.id).

Dengan melihat data tersebut, teknologi online shop akan semakin ramai karena beberapa tahun kedepan, pengguna internet di Indonesia akan bertambah dan bukannya hanya di Indonesia saja, namun seluruh dunia. Oleh karena itu, para pelaku ekonomi saat ini sudah beradaptasi dan berkolaborasi dengan adanya internet agar kegiatan ekonomi bisa terus berjalan tanpa terhalang oleh waktu dan tempat. Online shop sendiri sangat mudah dilakukan, karena tidak harus orang yang memiliki latar belakang bidang IT, banyak juga dari mereka yang asalnya dari ibu rumah tangga, pelajar, dan orang-orang yang asalnya bekerja di sebuah kantor, yang menggunakan online shop sebagai bisnis sampingan. Usaha belanja online atau toko online saat ini memang sedang menjamur dan ngetrend dikalangan penikmat dunia maya. Beragam cerita toko online dan seputar testimoni toko online pun semakin banyak dijumpai. Di Indonesia ini banyak yang sudah melakukan sistem belanja online, contohnya adalah bhinneka.com, lazada, bli-bli, tokobagus.com dan masih banyak toko online yang memberlakukan sistem jual beli online dalam menjual semua produknya.

Di zaman serba canggih seperti sekarang tidak perlu susah susah pergi ke toko atau mall untuk membeli barang kebutuhan, karena sekarang banyak yang menjual barang yang diperlukan via online atau buka toko lewat internet. Dengan online shop, konsumen bisa melihat produk selama 24 jam penuh tanpa adanya batas waktu penutupan. Jarak pun sudah tidak jadi halangan karena online shop bisa diakses dimana saja. Namun bukan berarti online shop tidak ada resiko atau ancaman serius yang dapat merugikan. Banyak kasus-kasus tindak kriminal atau hal yang merugikan yang berasal dari online shop, seperti penipuan, peretasan saat transfer, kerusakan barang dan lain sebagainya. Dengan resiko yang sudah disebutkan, seharusnya konsumen lebih waspada dan hati-hati jika bertransaksi secara online. Namun, yang terjadi justru malah sebaliknya. Konsumen saat ini cenderung melakukan transaksi secara online 
atau menggunakan dunia maya. Intensitas transaksi online dari tahun ke tahun terus menunjukan peningkatan. Seolah-olah konsumen mengabaikan resiko atau ancaman yang akan terjadi saat bertransaksi menggunakan online shop.

Berdasarkan uraian di atas terlihat faktor yang memengaruhi seseorang melakukan pembelian sangat beragam. Adi (2013) menyebutkan kemenarikan posting messages dan reputasi memengaruhi minat seseorang dalam melakukan pembelian online. Sementara Shim, Shin, \& Nottingham (2002) menjelaskan bahwa perilaku pembeli online sangat bergantung pada etersediaan informasi, kemenarikan desain website dan kemudahan dalam melakukan transaksi online. Keberadaan faktor tersebut akan memengaruhi sikap seseorang atas web yang menawarkan transaksi online. Sikap inilah yang nantinya mengakibatkan ke-putusan seseorang dalam melakukan pembelian online.

\section{B. TINJAUAN PUSTAKA Belanja Online}

Turban et al. (2004), Katawetawaraks dan Wang (2011) menjelaskan bahwa belanja online adalah kegiatan pembelian produk (baik barang ataupun jasa) melalui media internet. Kegiatan belanja online meliputi kegiatan Business to Business (B2B) maupun Business to Consumers (B2C). Sementara pada penelitian kegiatan belanja online dikaitkan dengan B2C karena kegiatan pembelian yang dimaksudkan adalah kegiatan pembelian yang digunakan oleh konsumen sendiri, tidak dijual kembali. Kegiatan belanja online di sini adalah transaksi yang bersifat ritel dengan pembeli individu, sehingga belanja online di sini adalah sebuah keputusan pembelian yang dilakukan oleh individu secara online. Salah satu manfaat dalam belanja online adalah calon pembeli dapat melihat terlebih dahulu (produk) yang akan dibelinya melalui web yang ditawarkan oleh penjual. Kegiatan ini sering disebut dengan searching.

Sementara itu, Kinnear dan Taylor (1995) serta Uddin, Lopa, \& Oheduzzaman (2014) mengemukakan bahwa faktor-faktor yang memengaruhi pembelian umumnya berkaitan dengan perasaan dan emosi. Kotler dan Keller (2013) menjelaskan bahwa proses pengambilan keputusan selalu berhubungan dengan situasi yang tidak terduga dan sikap terhadap pembelian.

\section{Sikap Berbelanja Online}

Seock dan Norton (2007), Rahayuningsih (2008), Prasad dan Aryasri (2009) mengemukakan bahwa sikap merupakan suatu bentuk perasaan yang bersifat favourable atau unfavourable. Dengan demikian, sikap pada dasarnya menunjukkan kondisi mental atau pun rasionalitas tertentu yang mencerminkan suatu pandangan pribadi mengenai suatu objek ataupun konsep. Pandangan tersebut dapat berupa pandangan yang positif (bermanfaat) dan pandangan negatif (destruktif). Kim, Ferrin, \& Rao, (2008) dan Shim, Eastlick, Lotz, \& Warrington (2001) selanjutnya menjelaskan bahwa sikap belanja online di sini merupakan faktor penyebab yang sangat penting dalam proses pengambilan keputusan pembelian online.

\section{Kemenarikan Desain Website}

Sarwono dan Prihartono (2012) mengemukakan bahwa teknik yang memudahkan akses dan publikasi informasi adalah menggunakan interaksi sosial melalui sosial media. Diseminasi informasi melalui sosial media selain mulai menjamur karena tingginya ikatan sosial dari pengguna juga merupakan cara baru yang lebih efektif dalam pencarian informasi. Dalam penyebaran informasi inilah, kemenarikan desain website menjadi salah satu pemandu yang handal guna mendorong calon konsumen untuk mengunjungi akun yang ada. Oleh karenanya semakin menarik desain website diharapkan mampu memantabkan keputusan berbelanja online. Selain itu kemenarikan desain website akan memengaruhi keinginan seseorang dalam melakukan belanja online. Keinginan tersebut merupakan perwujudan dari kepercayaan seseorang atas transaksi yang dilakukan. Kemenarikan desain website selain akan memunculkan rasa aman bahwa pihak vendor adalah penjual yang santun juga memunculkan rasa percaya bahwa penjual akan memenuhi apa yang dijanjikan (Broekhuizen \& Hui-zingh, 2009). 


\section{Reputasi Vendor}

Reputasi adalah citra yang melekat pada nama dari produk atau perusahaan yang memberi kesan kuat akan nama tersebut. Reputasi merupakan suatu identitas yang merupakan akumulasi nilai yang dilakukan oleh kelompok masyarakat ataupun konsumen. Herbig, Milewics, \& Golden (1994) menyatakan bahwa reputasi cenderung mencerminkan kompetensi dankeunggulan produk atau perusahaan dibandingkan pesaingnya. Reputasi umumnya berkaitan dengan pengalaman pelanggan, pembicaraan orang maupun pemberitaan media atas produk atau perusahaan tersebut.

Dalam konteks transaksi online, reputasi yang baik dapat dilakukan dengan memberi respons yang cepat dan ramah, pengiriman barang tepat waktu, pegiriman barang sesuai order serta kemudahan mengakses (Adi, 2013). Pelayanan yang baik akan mengurangi rasa khawatir calon konsumen mengenai transaksi online yang dilakukan. Adanya ketidakpuasan konsumen ketika bertransaksi online akan sangat menyebar di media sosial. Words of mouth negatif akan semakin sering bermunculan. Jika ini terjadi reputasi produk atau perusahaan yang melakukan transaksi online akan cepat terpuruk. Reputasi negatif pada akhirnya akan memengaruhi calon konsumen untuk melakukan transaksi belanja online (Williams, 2012). Selanjutnya Xu dan Yadav (2003) serta Kim dan Ahn (2007) menyatakan bahwa reputasi selain memengaruhi sikap seseorang dalam berbelanja online juga pada gilirannya memengaruhi keputusan pembelian online.

\section{Persepsi Kemudahan Transaksi}

Venkatesh dan Davis (2000) dan Pikkarainen, Pikkarainen, Karjaluoto, \& Pahnila (2004) menunjuk-kan bahwa kemudahan inilah yang menjadi faktor penting dalam belanja online. Kemudahan ini selain mudah dioperasionalisasikan juga berkaitan dapat dikurangi usaha seseorang (baik dari segi biaya, waktu dan tenaga) dalam melakukan transaksi. Kemudahan dalam berbelanja online akan menyebabkan calon konsumen tidak mengalami kesulitan dalam berbelanja online Schlosser (2003), Chiu, Lin, dan Tang (2005) serta Seock dan Norton (2007) mengemukakan bahwa sikap belanja online merupakan perasaan seseorang yang terkait dengan penilaiannya atas kegiatan transaksi yang dilakukan melalui internet. Selanjutnya, Wu (2003) dan Shen, Li, \& Demoss (2012) menambahkan bahwa suatu transaksi belanja online selain dipengaruhi oleh desain website dan reputasi juga dipengaruhi oleh kemudahan yang dapat dilakukan dalam bertransaksi.

\section{Kepercayaan (Trust)}

Kepercayaan merupakan hal yang paling penting ketika ingin berbelanja online, apakah website tersebut dapat dipercaya atau tidak dalam bertransaksi online. Kepercayaan menurut BA \& Pavlau (2002) adalah nilai dari hubungan seseorang dengan yang lainnya ketika akan melakukan sebuah transaksi dalam suatu lingkungan yang penuh dengan ketidakpastian menurut harapan kedua belah pihak. Kepercayaan konsumen akan layanan online menciptakan isu atau rumor yang menyebar begitu cepat tidak hanya secara online namun juga dalam dunia nyata (Ardyanto, dkk, 2015).

Semakin tinggi tingkat popularitas dari sebuah website maka semakin tinggi pula kepercayaan konsumen pada website tersebut, sehingga tidak ada keraguan bagi konsumen untuk membeli secara online melalui website tersebut. Dalam pembelian online sangat rentan deng adanyapenipuan karena kedua belah pihak antara penjual dan pembeli hanya mengandalkan kepercayaan sebagai modal dalam transaksi (Ardyanto, dkk, 2015).

\section{METODE}

Penelitian ini merupakan studi empiris dengan tujuan untuk mengetahui pengaruh antara Kemenarikan Desain Website (KDW), Reputasi Vendor (RV), Persepsi Kemudahan Transaksi (PKT), Sikap Belanja Online (SBO) dan Kepercayaan. Terhadap Keputusan Pembelian Online (KBO). Penelitian ini dilakukan pada Mahasiswa STIE AUB Surakarta tahun 2018.

Populasi adalah wilayah generalisasi yang terdiri dari atas objek/subjek yang mempunyai kualitas dan karakteristik tertentu yang ditetapkan oleh peneliti untuk dipelajari dan kemudian

ditarik kesimpulan (Sugiyono, 2012:119). Populasi dalam penelitian ini adalah Mahasiswa 
STIE AUB Surakarta yang pernah melakukan transaksi/belanja online.

Sampel yang diambil dalam penelitian ini adalah sejumlah $15 \%$ dari populasi (Arikunto, 2006:204) yaitu 749 mahasiswa STIE AUB Surakarta x 15\% = 112,35 responden kemudian dibulatkan menjadi 115 responden agar hasilnya lebih baik. Berdasarkan kriteria tersebut maka jumlah sampel dalam penelitian ini sebanyak 115 responden.

Data dalam penelitian ini diperoleh secara langsung dari sumber asli (tidak melalui media perantara).Data primer dalam penelitian ini diperoleh dari kuesioner yang diisi secara langsung.

Kuesioner yang disusun dengan mengacu pada beberapa penelitian yang sudah ada.

D. HASIL PENELITIAN

Uji Regresi Linear Berganda

Tabel I. Hasil Uji Regresi Linier Berganda

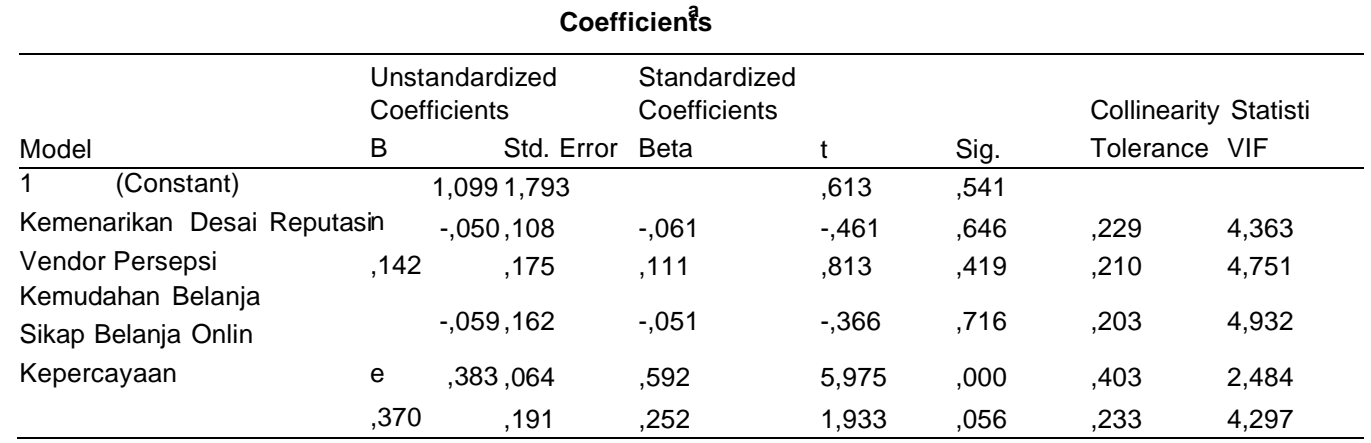

a. Dependent Variable: Keputusan Pembelian Online

Sumber: Data Hasil Penelitian, diolah 2018

Dari pengujian statistik diperoleh persamaan regresi sebagai berikut:

$Y=1,099-0,050 X_{1}+0,142 X_{2}-0,059 X_{3}+0,383 X_{4}+0,370 X_{5}$

Berdasarkan persamaan regresi tersebut maka dapat diinterprestasikan sebagai berikut:

1) Nilai konstanta $(\alpha)=1,099$ menunjukkan bahwa variabel Kemenarikan Desain, Reputasi Vendor, Persepsi Kemudahan Belanja, Sikap Belanja Online dan Kepercayaan tetap atau konstan, maka Keputusan Pembelian Online positif.

2) Nilai $\beta_{1}=-0,050$, menunjukkan bahwa variabel Kemenarikan Desain negatif dan tidak signifikan terhadap Keputusan Pembelian Online. Apabila variabel Kemenarikan Desain ditingkatkan maka akan menurunkan Keputusan Pembelian Online dengan asumsi variabel lain konstan.

3) Nilai $\beta_{2}=0,142$, menunjukkan bahwa variabel Reputasi Vendor berpengaruh positif namun tidak signifikan terhadap Keputusan Pembelian Online. Apabila variabel Reputasi Vendor ditingkatkan maka Keputusan Pembelian Online akan meningkat dengan asumsi variabel lain konstan.

4) Nilai $\beta_{3}=-0,059$, menunjukkan bahwa variabel Persepsi Kemudahan Belanja berpengaruh negatif namun tidak signifikan terhadap Keputusan Pembelian Online. Apabila variabel Persepsi Kemudahan Belanja ditingatkan maka Keputusan Pembelian Online semakin rendah dengan asumsi variabel lain konstan.

5) Nilai $\beta_{4}=0,383$ menunjukkan bahwa variabel Sikap Belanja Online berpengaruh positif dan signifikan terhadap Keputusan Pembelian Online. Apabila variabel Sikap Belanja Online ditingkatkan maka Keputusan Pembelian Online akan meningkat dengan asumsi variabel lain konstan.

6) Nilai $\beta_{5}=0,370$ menunjukkan bahwa variabel Kepercayaan berpengaruh positif namun 
tidak signifikan terhadap Keputusan Pembelian Online. Apabila variabel Kepercayaan ditingkatkan maka Keputusan Pembelian Online akan semakin rendah dengan asumsi variabel lain konstan.

\section{Hasil Uji T}

Berdasarkan hasil uji statistik t pada tabel 1. dapat disimpulkan sebagai berikut:

1) Pengaruh Kemenarikan Desain diperoleh nilai signifikansi sebesar 0,646>0,05 menunjukkan bahwa variabel Kemenarikan Desain berpengaruh tidak signifikan terhadap Keputusan Pembelian Online, sehingga hipotesis pertama $\left(\mathrm{H}_{1}\right)$ tidak terbukti.

2) Pengaruh Reputasi Vendor terhadap Keputusan Pembelian Online diperoleh nilai signifikansi sebesar 0,419 $<0,05$ menunjukkan bahwa variabel Reputasi Vendor berpengaruh tidak signifikan terhadap Keputusan Pembelian Online, sehingga hipotesis kedua $\left(\mathrm{H}_{2}\right)$ tidak terbukti.

3) Pengaruh Persepsi Kemudahan Belanja terhadap Keputusan Pembelian Online diperoleh nilai signifikansi sebesar $0,716<0,05$ menunjukkan bahwa variabel Persepsi Kemudahan Belanja berpengaruh tidak signifikan terhadap Keputusan Pembelian Online, sehingga hipotesis ketiga $\left(\mathrm{H}_{3}\right)$ tidak terbukti.

4) Pengaruh Sikap Belanja Online terhadap Keputusan Pembelian Online diperoleh nilai signifikansi sebesar $0,000<0,05$ menunjukkan bahwa variabel Sikap Belanja Online berpengaruh signifikan terhadap Keputusan Pembelian Online, sehingga hipotesis keempat $\left(\mathrm{H}_{4}\right)$ terbukti.

5) Pengaruh Kepercayaan terhadap Keputusan Pembelian Online diperoleh nilai signifikansi sebesar 0,056 $<0,05$ menunjukkan bahwa variabel Kepercayaan berpengaruh tidak signifikan terhadap Keputusan Pembelian Online, sehingga hipotesis keempat $\left(\mathrm{H}_{4}\right)$ tidak terbukti.

\section{Koefisien Determinasi Parsial (Adjusted $\mathbf{R}^{2}$ )}

Tabel II. Hasil Uji Koefisien Determinasi

\begin{tabular}{|c|c|c|c|c|c|}
\hline \multicolumn{6}{|c|}{ Model Summaryb } \\
\hline Model & $\mathrm{R}$ & R Square & $\begin{array}{l}\text { Adjusted } \\
\text { R Square }\end{array}$ & $\begin{array}{l}\text { Std. Error } \\
\text { the Estimate }\end{array}$ & ofDurbin- Watson \\
\hline 1 &, $792^{a}$ &, 628 &, 608 & 1,803 & 1,890 \\
\hline
\end{tabular}

Sumber: Data Hasil Penelitian, diolah 2018

Hasil uji Adjusted $R$ Square diperoleh hasil sebesar 0,608 menunjukkan bahwa variabel Keputusan Pembelian Online mampu dijelaskan oleh Variabel Kemenarikan Desain $\left(X_{1}\right)$, Reputasi Vendor $\left(\mathrm{X}_{2}\right)$, Persepsi Kemudahan Belanja $\left(\mathrm{X}_{3}\right)$, Sikap Belanja Online $\left(\mathrm{X}_{4}\right)$, dan Kepercayaan $\left(\mathrm{X}_{5}\right)$ sebesar 60,8\% sedangkan sisanya 39,2\% dijelaskan oleh variabel lain yang tidak termasuk dalam penelitian ini.

\section{E. PEMBAHASAN}

a. Pengaruh Kemenarikan Desain $\left(X_{1}\right)$ terhadap Keputusan Pembelian Online

Kemenarikan Desain $\left(\mathrm{X}_{1}\right)$ berpengaruh negatif dan tidak signifikan terhadap Keputusan Pembelian Online. Hal ini menunjukkan Semakin bagus kemenarikan website vendor justru akan menurunkan keputusan pemelian online. Ini menunjukkan bahwa variabel Kemenarikan Desain yang ada belum memberikan kontribusi sepenuhnya dalam Keputusan Pembelian Online. Melihat tren pembelian Online saat ini masyarakat terutama mahasiswa cenderung tidak melihat dari segi sisi kemenarikan desain website online, namun lebih melihat dari sisi ketersediaan produk-produk yang dibutuhkan oleh mahasiswa, dan kemudahan dalam akses pembayaran dan pengiriman barang. Hasil penelitian ini tidak mendukung penelitian yang telah dilakukan oleh Sarwono dan Prihartono (2012). 
b. Pengaruh Reputasi Vendor $\left(\mathrm{X}_{2}\right)$ terhadap Keputusan Pembelian Online

Reputasi Vendor $\left(\mathrm{X}_{2}\right)$ berpengaruh positif namun tidak signifikan terhadap Keputusan Pembelian Online. Hal ini menunjukkan semakin bagus Reputasi Vendor maka akan menaikkan keputusan pembelian online. Namun dalam hal ini Reputasi vendor tidak berpengaruh nyata terhadap keputusan mahasiswa dalam pembelian online walaupun vendor tersebut bagus ataupun sering muncul di iklan televisi. Hasil penelitian ini tidak mendukung penelitian Widiyanto dan Prasilowati (2015).

c. c. Pengaruh Persepsi Kemudahan Belanja $\left(\mathrm{X}_{3}\right)$ terhadap Keputusan Pembelian Online.

Persepsi Kemudahan Belanja $\left(\mathrm{X}_{3}\right)$ berpengaruh negatif dan tidak signifikan terhadap Keputusan Pembelian Online. Hasil Penelitian ini menunjukkan bahwa semakin tinggi Persepsi Kemudahan Belanja maka akan menurunkan Keputusan Pembelian Online. Penelitian ini juga tidak berpengaruh secara nyata terhadap keputusan pembelian online mahasiswa STIE AUB Surakarta. Hasil penelitian ini tidak mendukung penelitian yang telah dilakukan oleh Widiyanto dan Prasilowati (2015).

d. Pengaruh Sikap Belanja Online $\left(\mathrm{X}_{4}\right)$ terhadap Keputusan Pembelian Online.

Pengaruh Pemanfaatan Teknologi Informasi $\left(\mathrm{X}_{4}\right)$ berpengaruh positif dan signifikan terhadap Keputusan Pembelian Online. Hal ini dapat diartikan semakin tinggi sikap belanja online maka akan semakin meningkatkan keputusan pembelian online. Hasil penelitian berpengaruh nyata terhadap keputusan pembelian online mahasiswa STIE AUB. Hasil penelitian ini mendukung penelitian yang telah dilakukan oleh Widiyanto dan Prasilowati (2015).

e. Pengaruh Kepercayaan $\left(\mathrm{X}_{5}\right)$ terhadap Keputusan Pembelian Online.

Pengaruh Kepercayaan $\left(\mathrm{X}_{5}\right)$ berpengaruh positif namun tidak signifikan terhadap Keputusan Pembelian Online. Hal ini dapat diartikan semakin tinggi kepercayaan maka akan semakin meningkatkan keputusan pembelian online. Namun hasil penelitian tidak berpengaruh nyata terhadap keputusan pembelian online mahasiswa STIE AUB. Hasil penelitian ini tidak mendukung penelitian Sarwono dan Prihartono (2012).

\section{F. PENUTUP Simpulan}

1. Hasil Analisis Regresi Linier Berganda dapat diketahui bahwa :

a. Variabel Kemenarikan Desain berpengaruh negatif dan tidak signifikan terhadap Keputusan Pembelian Online.

b. Variabel Reputasi Vendor berpengaruh positif namun tidak signifikan terhadap Keputusan Pembelian Online.

c. Variabel Persepsi Kemudahan Belanja berpengaruh negatif dan tidak signifikan terhadap Keputusan Pembelian Online.

d. Variabel Sikap Belanja Online berpengaruh positif dan signifikan terhadap Keputusan Pembelian Online.

e. Variabel Kepercayaan berpengaruh positif namun tidak signifikan terhadap Keputusan Pembelian Online.

2. Sikap Belanja Online merupakan variabel yang paling mempengaruhi Keputusan Pembelian Online, kemudian diikuti dengan Kepercayaan, dan Reputasi Vendor.

3. Hasil Uji F menunjukkan bahwa secara bersama-sama variabel Kemenarikan Desain, Reputasi Vendor, Persepsi Kemudahan Belanja, Sikap Belanja Online, dan Kepercayaan berpengaruh signifikan terhadap Keputusan Pembelian Online.

4. Hasil uji Adjusted $R$ Square diperoleh hasil sebesar 0,696 menunjukkan bahwa variabel Keputusan Pembelian Online mampu dijelaskan oleh variabel Kemenarikan Desain $\left(\mathrm{X}_{1}\right)$, Reputasi Vendor $\left(\mathrm{X}_{2}\right)$, Persepsi Kemudahan Belanja $\left(\mathrm{X}_{3}\right)$, Sikap Belanja Online $\left(\mathrm{X}_{4}\right)$ dan Kepercayaan $\left(\mathrm{X}_{5}\right)$ sebesar $69,6 \%$ sedangkan sisanya $31,4 \%$ dijelaskan oleh variabel lain yang tidak termasuk dalam penelitian ini.

\section{Saran}

Saran yang dapat diberikan berdasarkan penelitian ini adalah sebagai berikut :

1. Faktor Penyebab utama keputusan pembelian online adalah Sikap Belanja Online. Ini 
berarti perusahaan perlu menjaga tingkat profesionalisme pengelolaan websitenya agar masyarakat selalu berfikir positif saat berbelanja online. Besarnya pengaruh adalah 0,383. Ini berarti besarnya pengaruh Sikap Belanja Online terhadap keputusan pembelian online adalah 0,383 .

2. Faktor kedua penyebab keputusan pembelian on-line adalah Kepercayaan. Ini berarti perusahaan perlu meminimalisir kasus penipuan melalui website agar konsumen semakin percaya dalam berbelanja online. Besarnya pengaruh adalah 0,370. Ini berarti besarnya pengaruh kepercayaan terhadap keputusan pembelian online adalah 0,370.

3. Faktor ketiga penyebab keputusan pembelian on-line adalah reputasi vendor. Ini berarti perusahaan perlu melakukan banyak kegiatan above the line campaign untuk mendukung peningkatan citra bisnis. Besarnya pengaruh adalah 0,142 . Ini berarti besarnya pengaruh reputasi vemdor terhadap keputusan belanja online adalah 0,142 .

\section{G. DAFTAR PUSTAKA}

Adi, R. N. (2013). Analisis faktor-faktor yang me-mengaruhi keputusan pembelian dengan sistem pre order secara online (Studi kasus pada online shop Chopper Jersey).

Anwar I \& Satrio B. (2015). Pengaruh Harga Dan Kualitas Produk Terhadap Keputusan Pembelian. Jurnal Ilmu dan Riset Manajemen, Vol 4, No 12.1-15.

Arikunto, S, (2010). Prosedur Penelitian : Suatu Pendektan Praktik. (Edisi Revisi). Jakarta : Rineka Cipta.

Best, R. J. (2013). Market-based management, strategies for growing customer value and profitabi-lity. New Jersey: Pearson Education, Inc.

Breckler, S. J. (1984). Empirical validation of affect, behavior, and cognition as distinct components of attitude. Journal of Personality and Social Psy-chology, 47 (6), 191205.

Chiu, Y., Lin, C., \& Tang, L. (2005). Gender differs: Assessing a model online purchase intention in e-tail service. Journal of Service Management, 16 (5), 416-435.

Davis, F. D. (1989). Perceived usefulness, perceived ease of use, and user acceptance of information technology. MIS Quarterly, 13(2), 318-340.

Ghozali, Imam. (2005). Aplikasi Multivariate dengan Program SPSS. Semarang: Universitas Diponegoro.

Hair, J. F., Black, W. J., Babin, B. J., \& Anderson, R. E. (2010). Multivariate data analysis, a global perspective. New Jersey: Pearson Prentice Hall.

Karimuddin, A. (2012). RE: MarkPlus insight: Jum-lah pengguna internet di Indonesia capai 61 juta orang. Diunduh 1 Maret 2015 dari https://dailysocial.net/post/markplus-insight- jumlah-peng-guna-internet-di-indonesia-capai-61juta-orang.

Katawetawaraks, C. \& Cheng, L. W. (2011). Online shopper behavior: Influences of online shopping decision. Asian Journal of Business Research, 1 (2), 66-74.

Li, D., Browne, G., \& Chau, P. (2006). An empirical investigation of website use using a commitment-based model. Decision Sciences, 37, 427-444. Mukherjee, A. \& Nath, P. (2003). A Model of trust in online relationship banking. International Journal of Marketing, 2l(1), 5-15.

Niazi, M. S., Haider, M. I., Islam, T., \& Rehman, S.U. (2012). The impact of corporate social responsi-bility on brand equity. European Journal of Social Sciences, 34, 520-529.

Sarwono, J. \& Prihartono. (2012). Perdagangan online: Cara bisnis di internet. Jakarta: PT Media Elex Komputindo. 
Sidharta, I \& Suzanto, B. (2015). Pengaruh Kepuasan Transaksi Online Shopping dan Kepercayaan Konsumen Terhadap Sikap Serta Perilaku Konsumen Pada ECommerce. Jurnal Computech \& Bisnis, Vol 9 No 1, 23-36.

Widiyanto, I \& Prasilowati S (2015). Perilaku Pembelian Melalui Internet. Journal JMK, Vol. 17, No. 2, , 109-112.

Williams, M. 2012. Relating word-of-mouth to cor-porate reputation. Public Communication Re-view, 2, 3-16.

Wolfinbarger, M. \& Gilly, M. (2003). E-tail q: Di-mensionalizing, measuring and predicting etail quality. Journal of Retailing, 27, 183-198.

$\mathrm{Wu}, \mathrm{S}$. I. (2003). The relationship between consumer characteristics an attitude toward online shop-ping. Management Intelligence and Planning, 21 (1), 37-44.

Xu, B. \& Yadav, S. (2003). Effect of online repute-tion services in electronic markets: A trust based empirical study. Ninth Americas Conference on Information Systems. Texas Tech University, Texas.

$\mathrm{Yu}, \mathrm{T}$. \& Wu, G. (2007). Determinants of internet shopping behavior: an application of reasoned behavior theory. International Journal of Mana-gement, 24(4), 744-762. 